\title{
Efficacy of different Potassium Sources on Quantitative and Qualitative Character of Litchi cv. Bombai grown in Indo-Gangetic Plain of West Bengal
}

\author{
Kaushik Das ${ }^{1} \geq 0$ and Pallab Dutta ${ }^{2}$
}

${ }^{1}$ Subject Matter Specialist Horticulture, Jalpaiguri Krishi Vigyan Kendra, WBUAFS, Ramshai, West Bengal (735 219$)$, India

${ }^{2}$ Dept. of Fruits and Orchard Management, Faculty of Horticulture, BCKV, Mohanpur, Nadia, West Bengal (741 252), India

Open Access

Corresponding $\$ kaushikdas.bckv@gmail.com

0000-0003-2417-4884

\section{ABSTRACT}

A field experiment was carried out at Regional Research Station, New Alluvial Zone, Bidhan Chandra Krishi Viswavidyalaya, Gayeshpur, Nadia, West Bengal, India during September 2014 to July 2017 to study the effect of different sources of potassium on fruit growth, yield and quality of Litchi cv. Bombai grown in Indo-gangetic plain of West Bengal. The experiment was laid out in Randomized Block Design consisting of seven treatments with three replications. All the plants were uniform in growth, 12 years of age and healthy spaced at $10 \times 10 \mathrm{~m}^{2}$. The results revealed that the application of different sources of potassium significantly improved the physico-chemical qualities and leaf mineral content of litchi. Among the different sources of potassium in the study, application of $\mathrm{KNO}_{3} @ 2 \%$ along with fixed doses of $\mathrm{N} @ 1000 \mathrm{~g}$ and $\mathrm{P}_{2} \mathrm{O}_{5} @ 500 \mathrm{~g}^{-1}$ plant $^{-1}$ year $^{-1}$ showed maximum vegetative growth in terms of plant height $(5.00 \mathrm{~m})$, spread $(\mathrm{N}-\mathrm{S}$ and $\mathrm{E}-\mathrm{W})$ while application of $\mathrm{K}_{2} \mathrm{SO}_{4} @$ $2 \%$ along with fixed doses of $\mathrm{N} @ 1000 \mathrm{~g}$ and $\mathrm{P}_{2} \mathrm{O}_{5} @ 500 \mathrm{~g} \mathrm{plant}^{-1} \mathrm{year}^{-1}$ showed highest fruit retention $\mathrm{m}^{-2}$ (32.50 no), yield $\left(72.60 \mathrm{~kg} \mathrm{plant}^{-1}\right)$, fruit weight $(23.03 \mathrm{~g})$, fruit length $(4.08 \mathrm{~cm})$, breadth $(3.30 \mathrm{~cm})$, aril weight $(15.99 \mathrm{~g})$, TSS $\left(19.17^{\circ}\right.$ Brix $)$, total sugar (14.98\%), lowest reducing sugar (11.19\%) with highest Vitamin C (32.83 mg $\left.100 \mathrm{~g}^{-1}\right)$, Anthocyanin content (38.02 $\left.\mathrm{mg} 100 \mathrm{~g}^{-1}\right)$ and highest mineral content (N, P, K, Ca, B and Zn) of the leaf.

KEYWORDS: Bombai, growth, litchi, leaf minerals, potassium, quality, yield

Citation (VANCOUVER): Das and Dutta, Efficacy of different Potassium Sources on Quantitative and Qualitative Character of Litchi cv. Bombai grown in Indo-Gangetic plain of West Bengal. International Journal of Bio-resource and Stress Management, 2022; 13(1), 45-52. HTTPS://DOI.ORG/10.23910/1.2022.2407.

Copyright: @ 2022 Das and Dutta. This is an open access article that permits unrestricted use, distribution and reproduction in any medium after the author(s) and source are credited.

Data Availability Statement: Legal restrictions are imposed on the public sharing of raw data. However, authors have full right to transfer or share the data in raw form upon request subject to either meeting the conditions of the original consents and the original research study. Further, access of data needs to meet whether the user complies with the ethical and legal obligations as data controllers to allow for secondary use of the data outside of the original study.

Conflict of interests: The authors have declared that no conflict of interest exists.

RECEIVED on $06^{\text {th }}$ June 2021 RECEIVED in revised form on $20^{\text {th }}$ December 2021 ACCEPTED in final form on $19^{\text {th }}$ January 2022 PUBLISHED on $33^{\text {st }}$ January 2022 


\section{INTRODUCTION}

T itchi (Litchi chinensis Sonn.), an indigenous crop of LSouth-East Asia, also recognized as "Queen of the fruits" is an important subtropical evergreen fruit tree belonging to the family Sapindaceae which produces sweet arillate fruits that are very succulent, juicy, aromatic and rich in vitamins and minerals. The major producing countries are China, India, Taiwan, Thailand, Myanmar, South Africa, Mauritius, Hawaii, Madagascar, Brazil, Vietnam, Pakistan, Australia, Israel and Florida (Ghosh, 2001). It was introduced in India by end of $17^{\text {th }}$ century to explore the possibilities of litchi cultivation due to the availability of convenient temperature and climatic conditions in some states of the country (Priyadarshi et al., 2018). Litchi fruits are rich in sugar contents $6.74-18.0 \%$, acid content 0.20 to $0.64 \%$ (malic acid, citric acid, levulinic acid, phosphoric acid, glutamic acid). It also contains $40-90 \mathrm{mg}$ vitamin- $\mathrm{C}^{-1} 100$ g edible portion, $0.9 \%$ protein, $0.3 \%$ fat, $0.42 \%$ pectin and $0.7 \%$ minerals $(\mathrm{Ca}, \mathrm{P}, \mathrm{Fe})$. Its skin also contains free radical scavenging compounds like ascorbic acid, carotenoids, polysaccharides (Yang et al., 2006) and phenolic substances flavonoids (flavonols and anthocyanins).

India ranks $2^{\text {nd }}$ in the world from the production point of view with cultivated area expansion of $30 \%$ in the last fifteen years, it occupies about 92 thousand hectares of land with 600 thousand metric tonnes of production and productivity of $6 \mathrm{mt} \mathrm{ha}^{-1}$ (Anonymous, 2018). Still, Litchi suffers from widespread problem of low and irregular bearing habits, poor fruit set, heavy fruit drop, fruit cracking and poor quality (Priyadarshi et al., 2018; Stern et al., 2000). Litchi has been identified as one of the potential fruit for export in India but the yield from the litchi orchards is often low and variable (Mandal et al., 2017). Hence, the production of quality fruit of international standard is of utmost importance. Fertilizer is one of the most important inputs for improving productivity and production of litchi orchards. Proper nutrient management is the key to achieving a higher yield and production of quality fruits. Inadequate nutrition often attributes to low yields in litchi (Menzel and Simpson, 1987) and poor quality of litchi fruit. It has been also observed that leaves and fruit absorbed most of the nutrients within 24-72 hours after spray and thereafter depletion of leaf nutrients content was noted due to translocation of $\mathrm{N}$, $\mathrm{P}$ and $\mathrm{K}$ to the active developing organs in the plant system (Singh et al., 2007). The supply of potassium in a balanced manner is very important for improving soil health and plant nutrition. The quality of the fruits, especially coloration of the skin, aroma, size, and shelf life, is improved when there is adequate K (Pathak and Mitra, 2010). Potassium is an important mineral for the proper function of all cells, tissues, and organs in the plant and also regulates other physiological processes such as photosynthesis, protein synthesis, phosphorylation, transportation of photo assimilates from source tissues via the phloem to sink tissues, enzyme activation, turgor pressure, transpiration, and stress tolerance. The magnificent role of $\mathrm{K}$ as a quality builder is also well established in many fruit crops. In West Bengal, Bombai is the choicest cultivar of litchi but very scanty information regarding the effect of potassium is available in literature. Thus, considering the importance of this mineral on fruit crops the present investigation was carried out to find the effect of different sources of potassium on plant morphological characters, yield and qualitative characters of litchi cv. Bombai in West Bengal.

\section{MATERIALS AND METHODS}

\subsection{Experimental site}

The present investigation was carried out at Regional Research Station, New Alluvial Zone, Bidhan Chandra Krishi Viswavidyalaya, Gayeshpur, Nadia, West Bengal, India $\left(22.57^{\circ} \mathrm{N}, 89.34^{\circ} \mathrm{E}\right.$, and $9.75 \mathrm{~m}$ above mean sea level) for three consecutive years from September 2014 to July 2017. The climate of the region is humid sub-tropical with hot-humid summers and cool winters. The mean annual rainfall is $1,750 \mathrm{~mm}$, out of which $80-90 \%$ is normally received from June to September. The soil at the experiment site was alluvial in nature and sandy loam in texture (sand $64.8 \%$, silt $10.4 \%$, and clay $24.8 \%$ ) with a $\mathrm{pH}$ of 6.6 and contained organic carbon of $0.68 \%$, available nitrogen $178.59 \mathrm{~kg} \mathrm{ha}^{-1}$, phosphorus $48.50 \mathrm{~kg} \mathrm{ha}^{-1}$ and potassium $273.12 \mathrm{~kg} \mathrm{ha}^{-1}$. Twelve years old healthy litchi plants cv. Bombai spaced at $10 \times 10 \mathrm{~m}^{2}$ apart having uniform growth and vigour were selected for the present study.

\subsection{Experimental design and crop husbandry}

The experiment was laid out in aRandomized Block Designcomprising of seven treatments with threereplications having two plants per replication. Various treatments of different sources of potassium in different concentrations were applied viz. $\mathrm{T}_{1}$ Potassium Nitrate $\left(\mathrm{KNO}_{3} @ 1 \%\right), \mathrm{T}_{2}$ Potassium Nitrate $\left(\mathrm{KNO}_{3} @ 2 \%\right), \mathrm{T}_{3}$ Potassium sulphate $\left(\mathrm{K}_{2} \mathrm{SO}_{4} @ 1 \%\right), \mathrm{T}_{4}$ Potassium sulphate $\left(\mathrm{K}_{2} \mathrm{SO}_{4} @ 2 \%\right), \mathrm{T}_{5}$ Potassium chloride ( $\mathrm{KCl} @ 1 \%$ ), $\mathrm{T}_{6}$ (Potassium chloride ( $\mathrm{KCl} @ 2 \%$ ), and $\mathrm{T}_{7}$ Control (water spray).The above treatments were applied separately along with fixed doses of $\mathrm{N} @ 1000 \mathrm{~g}$ and $\mathrm{P}_{2} \mathrm{O}_{5} @ 500 \mathrm{~g}$ plant $^{-1}$ year ${ }^{-1}$ as soil application in two split doses once after fruit set and remaining after harvest of fruit (June-July). The different sources of potassium were applied as foliar spray thrice starting from September, October and November through a foot sprayer. A standard package of practiceswas followed for growing plants and plant protection measureswere taken accordingly through chemical means. 


\subsection{Methods of data collection}

The physicochemical analysis was made following all standard methods as described by Ranganna (2003). The best yield indicator in fruit crops i.e. fruit retention was measuredby the formula given by Sau et al., 2016.

Fruit retention $\%=$ No. of retained fruits (at harvest) $/$ No. of settled fruits initially $\times 100$

Observations of fruit physical parameters like fruit size (lengthand diameter) were done with the help of Vernier Calipers. Fruit weight, Pulp and aril weight with the help of digital weighing balance wasbased on random ten fruit samples. Biochemical fruit quality wasdetermined from the juice extracted from 10 fruit. The Total Soluble Solid (TSS) was estimated using a digital refractometer (ATAGO, RX 5000, Tokyo, Japan) and was expressed as ${ }^{\circ}$ Brix. Titratable acidity was determined by titrating $5 \mathrm{ml}$ of juice against $0.1 \mathrm{~N} \mathrm{NaOH}$ and expressed as \% (Anonymous, 2000). Ascorbicacid (mg $\left.100 \mathrm{~g}^{-1}\right)$ content of the guava fruit was estimated by using 2, 6-dichlorophenolindophenol dye titration method (Casanas et al., 2002). Total sugar (\%), reducing sugar (\%) and non-reducing sugar (\%) were determined as per the guidelines of Anonymous (2000).

\subsection{Leaf nutrient content determination}

For the determination of leaf mineral contents (N, P and $\mathrm{K}$ ), fiftyrecently mature $3^{\text {rd }}$ pair leaves from the apexwere selected from a non-fruitingshoot at random. Three months old leaf samples in the month of October were taken from the middle portion of the lamina to the width of about 15 $\mathrm{cm}$ on both sides of the midrib for leaf mineral analysis. Leaf samples were washed with ordinary detergent, rinsed well with distilled water and dried in the oven at $70^{\circ} \mathrm{C}$ for $48 \mathrm{~h}$. After drying, leaves were grinded into fine powder using an electric grinder. Then the powder samples were used for analysing total $\mathrm{N}$ by micro-kjeldhal steam distillation method (Anonymous, 2000). The samples were further digested in di-acid (nitric acid, perchloric acid in 9:4 v/v ratio) mixture and used for analysing phosphorus using Vanadomolybdo phosphoric acid method, K using flame photometer Murray (1960). For micronutrient content the samples were further digested in the di-acid mixture $\left(\mathrm{HNO}_{3}: \mathrm{HClO}_{4} 10: 4\right)$ and analyzed for micronutrient (Fe, $\mathrm{Mn}, \mathrm{Zn}$ and $\mathrm{Cu}$ ) content following the methods as described by Lindsay and Norvell (1978) by using Atomic Absorption Spectrophotometer and $\mathrm{Ca}, \mathrm{Mg}, \mathrm{S}$ and $\mathrm{B}$ by following the methods described by Jackson (1967).

\section{RESULTS AND DISCUSSION}

\subsection{Effect of different sources of potassium on physical growth parameters of litchi}

Data on the effect of different sources of potassium on different physical parameters of litchi plant cv. Bombai has been presented in Table 1.
Table 1: Effect of different sources of potassium on physical parameters of litchi plant cv. Bombai

\begin{tabular}{lccccc}
$\begin{array}{l}\text { Treat- } \\
\text { ments }\end{array}$ & $\begin{array}{c}\text { Plant } \\
\text { height } \\
(\mathrm{m})\end{array}$ & $\begin{array}{c}\text { Plant } \\
\text { spread } \\
(\mathrm{N}-\mathrm{S} \\
\text { in m) }\end{array}$ & $\begin{array}{c}\text { Plant } \\
\text { spread } \\
(\mathrm{E}-\mathrm{W} \mathrm{m})\end{array}$ & $\begin{array}{c}\text { Plant } \\
\text { girth } \\
(\mathrm{cm})\end{array}$ & $\begin{array}{c}\text { Fruit } \\
\text { retention } \\
\mathrm{m}^{-2}(\%)\end{array}$ \\
\hline $\mathrm{T}_{1}$ & $4.77^{\mathrm{ab}}$ & $6.30^{\mathrm{cd}}$ & $6.11^{\mathrm{ab}}$ & $66.84^{\mathrm{ab}}$ & $29.00^{\mathrm{ab}}$ \\
$\mathrm{T}_{2}$ & $5.00^{\mathrm{b}}$ & $6.42^{\mathrm{d}}$ & $7.20^{\mathrm{c}}$ & $67.00^{\mathrm{ab}}$ & $29.67^{\mathrm{ab}}$ \\
$\mathrm{T}_{3}$ & $4.60^{\mathrm{a}}$ & $5.83^{\mathrm{bcd}}$ & $6.12^{\mathrm{ab}}$ & $68.00^{\mathrm{ab}}$ & $28.84^{\mathrm{ab}}$ \\
$\mathrm{T}_{4}$ & $4.76^{\mathrm{ab}}$ & $5.85^{\mathrm{bcd}}$ & $6.29^{\mathrm{b}}$ & $72.83^{\mathrm{b}}$ & $32.50^{\mathrm{b}}$ \\
$\mathrm{T}_{5}$ & $4.52^{\mathrm{a}}$ & $5.78^{\mathrm{bc}}$ & $6.23^{\mathrm{b}}$ & $67.67^{\mathrm{ab}}$ & $29.33^{\mathrm{ab}}$ \\
$\mathrm{T}_{6}$ & $4.68^{\mathrm{ab}}$ & $5.45^{\mathrm{ab}}$ & $5.70^{\mathrm{a}}$ & $68.00^{\mathrm{ab}}$ & $31.34^{\mathrm{b}}$ \\
$\mathrm{T}_{7}$ & $4.44^{\mathrm{a}}$ & $5.18^{\mathrm{a}}$ & $5.59^{\mathrm{a}}$ & $64.34^{\mathrm{a}}$ & $26.17^{\mathrm{a}}$ \\
$\mathrm{SEm} \pm$ & 0.12 & 0.20 & 0.17 & 2.05 & 1.08 \\
$\mathrm{DMRT}$ & $\mathrm{S}$ & $\mathrm{S}$ & $\mathrm{S}$ & $\mathrm{S}$ & $\mathrm{S}$ \\
$p=0.05$ & & & & & \\
\hline
\end{tabular}

$\mathrm{T}_{1}: \mathrm{KNO}_{3} 1 \% ; \mathrm{T}_{2}: \mathrm{KNO}_{3} 2 \% ; \mathrm{T}_{3}: \mathrm{K}_{2} \mathrm{SO}_{4} 1 \% ; \mathrm{T}_{4}: \mathrm{K}_{2} \mathrm{SO}_{4}$ $2 \% ; \mathrm{T}_{5}: \mathrm{KCl} \mathrm{1 \%} ; \mathrm{T}_{6}: \mathrm{KCl} 2 \% ; \mathrm{T}_{7}:$ Control

The different sources of potassium significantly influenced the different physical growth parameters of litchi plant cv. Bombai by increasing the plant height, canopy spread in both direction (N-S; E-W), plant girth and fruit retention $\mathrm{m}^{-2}$ as presented in Table 1. Polled data of two years suggested that among the different sources of potassium maximum plant height $5.00 \mathrm{~m}$ was obtained for $\mathrm{T}_{2}\left(\mathrm{KNO}_{3}\right.$ @ 2\%) application along with a fixed dose of Nitrogen and Phosphorus followed by $(4.77 \mathrm{~m})$ in $\mathrm{T}_{1}\left(\mathrm{KNO}_{3} @ 1 \%\right)$ and $4.76 \mathrm{~m}$ in $\mathrm{T}_{4}\left(\mathrm{~K}_{2} \mathrm{SO}_{4} 2 \%\right)$, while the control plants recorded the minimum $(4.44 \mathrm{~m})$ plant height. Like plant height, canopy spread in both the direction, plant girth and fruit retention $\mathrm{m}^{-2}$ was also affected by different sources of potassium. From the pooled analysis, as observed it was found that the canopy spread in the North-South direction showed a maximum of $6.42 \mathrm{~m}$ in $\mathrm{T}_{2}\left(\mathrm{KNO}_{3} 2 \%\right)$ followed by $6.30 \mathrm{~m}$ in $\mathrm{T}_{1}\left(\mathrm{KNO}_{3} 1 \%\right)$ which was at par with $\mathrm{T}_{1}$ and the least spread $5.18 \mathrm{~m}$ was found in $\mathrm{T}_{7}$ (control) while polled data for canopy spread in East-West direction also recorded similar trends with the maximum $7.20 \mathrm{~m}$ spread in $\mathrm{T}_{2}\left(\mathrm{KNO}_{3} 2 \%\right)$ followed by $6.29 \mathrm{~m}$ in $\mathrm{T}_{4}\left(\mathrm{~K}_{2} \mathrm{SO}_{4} 2 \%\right)$ and the minimum $5.59 \mathrm{~m}$ was found from $\mathrm{T}_{7}$ (control) plants. A perusal of pooled data regarding girth of plant in litchi showed a maximum of $72.83 \mathrm{~cm}$ in $\mathrm{T}_{4}\left(\mathrm{~K}_{2} \mathrm{SO}_{4} 2 \%\right)$ application followed by $68.00 \mathrm{~cm}$ in both $\mathrm{T}_{3}\left(\mathrm{~K}_{2} \mathrm{SO}_{4} 1 \%\right)$ and $\mathrm{T}_{6}(\mathrm{KCl} 2 \%)$ while the least plant girth $64.34 \mathrm{~cm}$ was found in control plants. Pooled data for fruit retention $\mathrm{m}^{-2}$ of the plant also showed similar trends with the maximum percentage of 32.50 was observed in $\mathrm{T}_{4}\left(\mathrm{~K}_{2} \mathrm{SO}_{4} 2 \%\right)$ application followed by $31.34 \%$ in $\mathrm{T}_{6}(\mathrm{KCl} 2 \%)$, which was 
at par with $\mathrm{T}_{4}$ while the least fruit retention $\mathrm{m}^{-2} 26.17$ was found from control plants $\left(\mathrm{T}_{7}\right)$.

Application of $\mathrm{KNO}_{3} @ 2 \%$ showed a marked effect on plant height and spread while $\mathrm{K}_{2} \mathrm{SO}_{4} @ 2 \%$ showed maximum plant girth and fruit retention $\mathrm{m}^{-2}$ at harvest. Improvement in plant characters was more marked with a higher concentration of different sources of potassium than their respective lower concentration. This might be due to the effect of potassium on plant physical characters. A similar observation was obtained by Yang et al. (2015a) in litchi cv. Feizixiao. The increase in the number and size of fruits due to the application of potassium may be attributed to the improvement in vegetative growth of the plant as well as the efficient transfer of photosynthates to the economic part of the plant. According to Nijjar (1990), potassium might have acted as activation for a number of complex enzyme systems and these enzymes catalyze metabolic reactions related to the carbohydrates, nucleic acid and nucleotides, amino acids, protein and folic acid. Foliar spray of potassium might improve leaf photosynthetic $\mathrm{CO}_{2}$ assimilation; assimilate translocation from leaves to fruits, increased enzyme activation and substrate availability (Hopkins, 1963 and Gross, 1991).The application of potassium can accelerate fibre compounding and epidermal tissue development, thicken the cell wall, and improve the mechanical resistance of collenchymas against bacterial parasites Yang et al. (2015a).

3.2. Effect of different sources of potassium on various yield attributes of mature litchi fruits cv. Bombai

Data on the effect of different sources of potassium on different yield attributes of mature litchi fruits $\mathrm{cv}$. Bombai has been presented in Table 2 .

\begin{tabular}{lcccccc}
\hline \multicolumn{6}{l}{ Table 2: Effect of different sources of potassium on various yields attributes of mature litchi fruits } \\
\hline Treatments & $\begin{array}{c}\text { Yield } \\
\left(\mathrm{kg} \mathrm{plant}^{-1}\right)\end{array}$ & $\begin{array}{c}\text { Fruit wt } \\
(\mathrm{g})\end{array}$ & $\begin{array}{c}\text { Fruit length } \\
(\mathrm{cm})\end{array}$ & $\begin{array}{c}\text { Fruit breadth } \\
(\mathrm{cm})\end{array}$ & $\begin{array}{c}\text { Aril wt } \\
(\mathrm{g})\end{array}$ & $\begin{array}{c}\text { Seed wt } \\
(\mathrm{g})\end{array}$ \\
\hline $\mathrm{T}_{1}$ & $56.86^{\mathrm{ab}}$ & $19.16^{\mathrm{ab}}$ & $3.60^{\mathrm{b}}$ & 3.04 & $14.06^{\mathrm{abc}}$ & $3.26^{\mathrm{ab}}$ \\
$\mathrm{T}_{2}$ & $61.35^{\mathrm{b}}$ & $20.27^{\mathrm{bc}}$ & $3.70^{\mathrm{b}}$ & 3.13 & $14.20^{\mathrm{bcd}}$ & $3.15^{\mathrm{ab}}$ \\
$\mathrm{T}_{3}$ & $60.79^{\mathrm{b}}$ & $20.56^{\mathrm{bc}}$ & $3.68^{\mathrm{b}}$ & 3.07 & $15.11^{\mathrm{bcd}}$ & $3.28^{\mathrm{ab}}$ \\
$\mathrm{T}_{4}$ & $72.60^{\mathrm{d}}$ & $23.03^{\mathrm{d}}$ & $4.08^{\mathrm{c}}$ & 3.30 & $15.99^{\mathrm{d}}$ & $3.18^{\mathrm{ab}}$ \\
$\mathrm{T}_{5}$ & $64.25^{\mathrm{bc}}$ & $21.40^{\mathrm{cd}}$ & $3.71^{\mathrm{b}}$ & 3.15 & $13.26^{\mathrm{ab}}$ & $3.10^{\mathrm{ab}}$ \\
$\mathrm{T}_{6}$ & $71.24^{\mathrm{cd}}$ & $21.73^{\mathrm{cd}}$ & $3.91^{\mathrm{bc}}$ & 3.16 & $15.82^{\mathrm{cd}}$ & $2.97^{\mathrm{a}}$ \\
$\mathrm{T}_{7}$ & $51.08^{\mathrm{a}}$ & $17.76^{\mathrm{a}}$ & $3.17^{\mathrm{a}}$ & 2.84 & $13.1^{2 \mathrm{a}}$ & $3.32^{\mathrm{b}}$ \\
$\mathrm{SEm} \pm$ & 2.72 & 0.27 & 0.12 & 0.14 & 0.50 & 0.10 \\
DMRT $p=0.05$ & $\mathrm{~S}$ & $\mathrm{~S}$ & $\mathrm{~S}$ & $\mathrm{NS}$ & $\mathrm{S}$ & $\mathrm{S}$ \\
\hline
\end{tabular}

$\mathrm{T}_{1}: \mathrm{KNO}_{3} 1 \% ; \mathrm{T}_{2}: \mathrm{KNO}_{3} 2 \% ; \mathrm{T}_{3}: \mathrm{K}_{2} \mathrm{SO}_{4} 1 \% ; \mathrm{T}_{4}: \mathrm{K}_{2} \mathrm{SO}_{4} 2 \% ; \mathrm{T}_{5}: \mathrm{KCl} 1 \% ; \mathrm{T}_{6}: \mathrm{KCl} 2 \% ; \mathrm{T}_{7}:$ Control

A perusal of data from Table 2 clearly indicated that different sources of potassium significantly influenced the physicochemical composition of mature litchi fruit in terms of yield, fruit weight, fruit length, fruit breadth, aril weight, seed weight and aril: seed ratio. Pooled analysis of two years regarding yield data clearly suggested that statistically significant variation was observed in litchi plants with the highest yield $72.60 \mathrm{~kg}$ plant $^{-1}$ was obtained from application in $\mathrm{T}_{4}\left(\mathrm{~K}_{2} \mathrm{SO}_{4} 2 \%\right)$ followed by $71.24 \mathrm{~kg}$ plant $^{-1}$ in $\mathrm{T}_{6}(\mathrm{KCl} 2 \%)$ which was statistically at par with $\mathrm{T}_{4}$ while the lowest yield $51.08 \mathrm{~kg}$ plant $^{-1}$ was obtained from the control plants $\left(\mathrm{T}_{7}\right)$. This clearly indicated that by spraying potassium sulphate $\left(\mathrm{K}_{2} \mathrm{SO}_{4}\right) @ 2 \%$ in $\mathrm{T}_{4}$ the yield of litchi fruit in $\mathrm{kg}_{\text {plant }}{ }^{-1}$ was increased by $21.52 \mathrm{~kg}$ over control plants. In the same way, the fruit weight and fruit length were found statistically significant with the application of different potassium sources and the maximum fruit weight $23.03 \mathrm{~g}$ was obtained from $\mathrm{T}_{4}\left(\mathrm{~K}_{2} \mathrm{SO}_{4} 2 \%\right)$ followed by 21.73 $\mathrm{g}$ from $\mathrm{T}_{6}(\mathrm{KCl} 2 \%)$ while minimum fruit weight $17.76 \mathrm{~g}$ was recorded from control plant. Significantly differences among fruit length were observed due to different treatment of K. Maximum $(4.08 \mathrm{~cm})$ length of individual fruit was noted from $\mathrm{T}_{4}$ followed by $(3.91 \mathrm{~cm})$ in $\mathrm{T}_{6}$ while the least was recorded from control plants. Like fruit length, breadth of fruit was also influenced by the application of different sources of potassium with $\mathrm{T}_{4}\left(\mathrm{~K}_{2} \mathrm{SO}_{4} @ 2 \%\right)$ recording maximum $(3.30 \mathrm{~cm})$ breadth of fruit which is at par with $\mathrm{T}_{6}$ $(3.16 \mathrm{~cm})$ while control fruit recorded minimum $(2.84 \mathrm{~cm})$. Application of different sources of potassium significantly increased the aril weight and decreases the seed weight of fruits per plant as compared to the control plant. $\mathrm{T}_{4}\left(\mathrm{~K}_{2} \mathrm{SO}_{4}\right.$ @ 2\%) treated plants recorded maximum aril weight (15.99 g) followed by $(15.82 \mathrm{~g})$ in $\mathrm{T}_{6}(\mathrm{KCl} 2 \%)$ while minimum $(13.16 \mathrm{~g})$ was obtained from control plants. The seed weight was found maximum in control plants $\mathrm{T}_{7}(3.32 \mathrm{~g})$ while the least $2.97 \mathrm{~g}$ was obtained in $\mathrm{KCl} @ 2 \%$ treated plants. 
The pooled data regarding aril: seed ratio showed to be statistically significant in all the years with the maximum value 5.10 was found with the application of $\mathrm{K}_{2} \mathrm{SO}_{4} 2 \%$ while the lowest 4.12 was obtained from $\mathrm{T}_{6}(\mathrm{KCl} 2 \%)$ treated plants as shown in Figure 1.

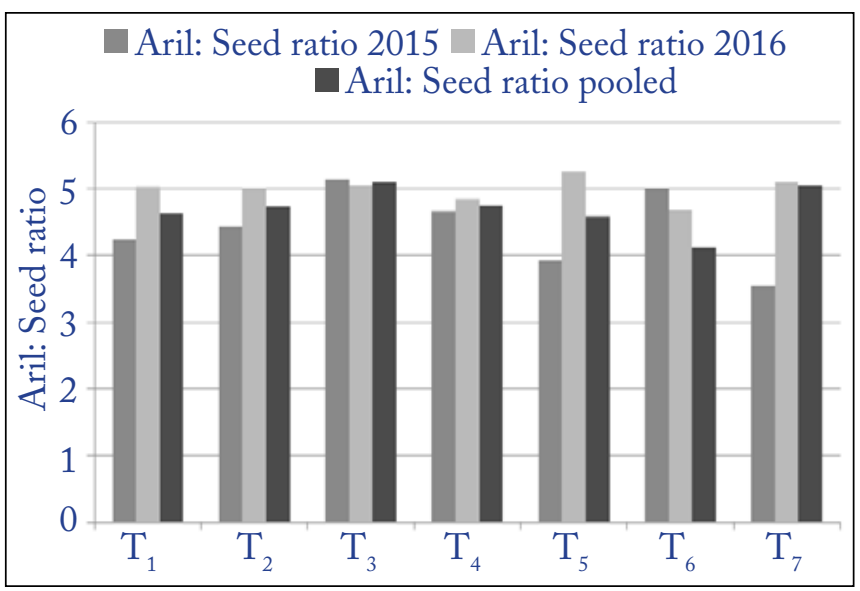

Figure 1: Effect of different sources of potassium on Aril: Seed ratio of litchi fruit cv. Bombai

Application of potassium as foliar spray from different sources viz, $\mathrm{K}_{2} \mathrm{SO}_{4}$ and $\mathrm{KCl}$ showed marked effect on plant characters, fruit weight and yield and other yield attributes of the crop. Foliar spray of the different sources of potassium showed a significant effect on fruit weight, fruit length and breadth, aril weight and yield tree ${ }^{-1} \cdot \mathrm{K}_{2} \mathrm{SO}_{4}$ @ 2\% recorded maximum fruit weight and yield per tree. Cline and Bradt (1980) also observed a greater increase in berry yield with $\mathrm{K}_{2} \mathrm{SO}_{4}$ or $\mathrm{KCl}$ treatments than with $\mathrm{KNO}_{3}$. Cohen (1976) observed that potassium application not only increased the fruit size but also improved the rind thickness in citrus fruit. Thus it was found $\mathrm{K}_{2} \mathrm{SO}_{4} @ 2 \%$ showed more beneficial in increasing individual fruit weight and yield. The improvement in fruit weight with potassium spray might be due to increased photosynthesis which results in the supply of more carbohydrates to the fruits. Potassium is an important nutrient for fruit weight and improvement in fruit quality and it is required for the production and transport of plant sugars which in turn intend to increase the fruit weight (Menzel, 1983). These results are in conformity with the finding of Pathak and Mitra (2010) who observed an improvement in fruit weight with higher leaf $\mathrm{K}$ content in litchi cultivar. The results also find support by Gill et al. (2012) in Patharnakh pear, Dutta et al. (2011) and Das et al. (2017) in mango cv. Himsagar.

\subsection{Effect of different sources of potassium on bio-chemical composition of mature litchi fruits cv. Bombai}

Data on the effect of different sources of potassium on the different biochemical compositions of mature litchi fruits cv. Bombai has been presented in Table 3.

Table 3: Effect of different sources of potassium on qualitative characters of mature litchi fruits cv. Bombai

\begin{tabular}{|c|c|c|c|c|c|c|}
\hline Treatments & $\begin{array}{l}\text { TSS } \\
\left({ }^{\circ} \text { Brix }\right)\end{array}$ & $\begin{array}{l}\text { Total sugar } \\
(\%)\end{array}$ & $\begin{array}{c}\text { Reducing sugar } \\
(\%)\end{array}$ & $\begin{array}{l}\text { Ascorbic acid } \\
\left(\mathrm{mg} 100 \mathrm{~g}^{-1}\right)\end{array}$ & $\begin{array}{l}\text { Anthocyanin content } \\
\quad\left(\mathrm{mg} 100 \mathrm{~g}^{-1}\right)\end{array}$ & $\begin{array}{l}\text { Titratable } \\
\text { acidity (\%) }\end{array}$ \\
\hline $\mathrm{T}_{1}$ & $18.12^{\mathrm{ab}}$ & $13.52^{\mathrm{a}}$ & $11.19^{a}$ & $31.27^{\mathrm{b}}$ & $26.64^{\mathrm{ab}}$ & $0.36^{\mathrm{a}}$ \\
\hline $\mathrm{T}_{2}$ & $17.42^{\mathrm{ab}}$ & $13.48^{\mathrm{a}}$ & $11.40^{\mathrm{a}}$ & $31.53^{\mathrm{b}}$ & $32.62^{\mathrm{b}}$ & $0.44^{\mathrm{b}}$ \\
\hline $\mathrm{T}_{3}$ & $18.50^{\mathrm{a}}$ & $13.36^{\mathrm{a}}$ & $11.36^{\mathrm{a}}$ & $29.27^{\mathrm{ab}}$ & $31.19^{\mathrm{b}}$ & $0.38^{\mathrm{ab}}$ \\
\hline $\mathrm{T}_{4}$ & $19.17^{c}$ & $14.98^{\mathrm{b}}$ & $11.05^{\mathrm{a}}$ & $32.83^{b}$ & $38.02^{c}$ & $0.38^{\mathrm{ab}}$ \\
\hline $\mathrm{T}_{5}$ & $18.33^{\mathrm{bc}}$ & $14.62^{a}$ & $11.88^{a}$ & $31.58^{\mathrm{b}}$ & $31.61^{\mathrm{b}}$ & $0.42^{\mathrm{ab}}$ \\
\hline $\mathrm{T}_{6}$ & $18.38^{\mathrm{abc}}$ & $14.06^{\mathrm{a}}$ & $11.67^{a}$ & $30.62^{\mathrm{b}}$ & $35.20^{\mathrm{bc}}$ & $0.41^{\mathrm{ab}}$ \\
\hline $\mathrm{T}_{7}$ & $16.62^{\mathrm{a}}$ & $13.12^{\mathrm{a}}$ & $13.03^{\mathrm{b}}$ & $25.73^{a}$ & $26.29^{a}$ & $0.51^{\mathrm{c}}$ \\
\hline SEm \pm & 0.40 & 0.34 & 0.34 & 2.78 & 1.50 & 0.02 \\
\hline DMRT $p=0.05$ & $\mathrm{~S}$ & $S$ & $\mathrm{~S}$ & $\mathrm{~S}$ & $\mathrm{~S}$ & $\mathrm{~S}$ \\
\hline
\end{tabular}

$\mathrm{T}_{1}: \mathrm{KNO}_{3} 1 \% ; \mathrm{T}_{2}: \mathrm{KNO}_{3} 2 \% ; \mathrm{T}_{3}: \mathrm{K}_{2} \mathrm{SO}_{4} 1 \% ; \mathrm{T}_{4}: \mathrm{K}_{2} \mathrm{SO}_{4} 2 \% ; \mathrm{T}_{5}: \mathrm{KCl} \mathrm{1 \%} \mathrm{T}_{6}: \mathrm{KCl} 2 \% ; \mathrm{T}_{7}:$ Control

Bio-chemical compositions of fruits were also influenced by the application of different sources of potassiumas evident in Table 3. The different treatments of $\mathrm{K}$ showed statistically significant variation and increased the total soluble solids content of fruits. Maximum $\left(19.17^{\circ} \mathrm{Brix}\right) \mathrm{TSS}$ content was measured in $\mathrm{T}_{4}\left(\mathrm{~K}_{2} \mathrm{SO}_{4} 2 \%\right)$ followed by $\left(18.50{ }^{\circ} \mathrm{Brix}\right)$ in $\mathrm{T}_{3}$ $\left(\mathrm{K}_{2} \mathrm{SO}_{4} 1 \%\right)$, while the minimum $\left(16.62^{\circ} \mathrm{Brix}\right)$ was noted in $\mathrm{T}_{7}$ (control) plants. Statistically significant influence was also observed in the case of total sugar and reducing sugar by the application of different sources of potassium. Pooled analysis of data in both years revealed a maximum sugar percentage of $14.98 \%$ in $\mathrm{T}_{4}\left(\mathrm{~K}_{2} \mathrm{SO}_{4} 2 \%\right)$ followed by $14.62 \%$ in $\mathrm{T}_{5}(\mathrm{KCl} 1 \%)$ which was statistically at par with $\mathrm{T}_{4}$ while the minimum total sugar $13.12 \%$ was found from control fruits $\left(\mathrm{T}_{7}\right)$. Pooled data analysis also revealed the lowest reducing sugar $11.19 \%$ from $\mathrm{T}_{4}\left(\mathrm{~K}_{2} \mathrm{SO}_{4} 2 \%\right)$ 
while the highest reducing sugar (13.03\%) was obtained from control $\mathrm{T}_{7}$. Other quality parameters like ascorbic acid, anthocyanin content and titrable acidity of fruit were statistically significantly influenced by different treatments of potassium. Among the different sources, here also application of $\mathrm{K}_{2} \mathrm{SO}_{4} @ 2 \%\left(\mathrm{~T}_{4}\right)$ pooled data recorded

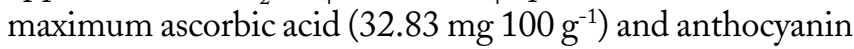
content $\left(38.02 \mathrm{mg} 100 \mathrm{~g}^{-1}\right)$ of fruit while the minimum $\left(25.73 \mathrm{mg} 100 \mathrm{~g}^{-1}\right)$ ascorbic acid and anthocyanin content (26.29 mg $100 \mathrm{~g} \mathrm{~g}^{-1}$ ) was obtained from $\mathrm{T}_{7}$ (control) plants. Application of different sources of potassium significantly decreased the titratable acid content of fruit with minimum acidity $0.36 \%$ obtained from the application of $\mathrm{KNO}_{3} 1 \%$ in $\left(\mathrm{T}_{1}\right)$ which is at par with $0.38 \%$ in $\mathrm{T}_{4}$ and $\mathrm{T}_{3}$, while the maximum acidity of $0.51 \%$ was obtained from control plants $\left(\mathrm{T}_{7}\right)$. Graphical representation on TSS: acid ratio of litchi fruits as influenced by application by different sources of potassium has been presented in which it was observed that pooled analysis of data in both years showed maximum value 51.45 in $\mathrm{T}_{4}\left(\mathrm{~K}_{2} \mathrm{SO}_{4} 2 \%\right)$ while the minimum TSS: acid ratio (33.23) was obtained from $\mathrm{T}_{7}$ (control) plants as observed in Figure 2.

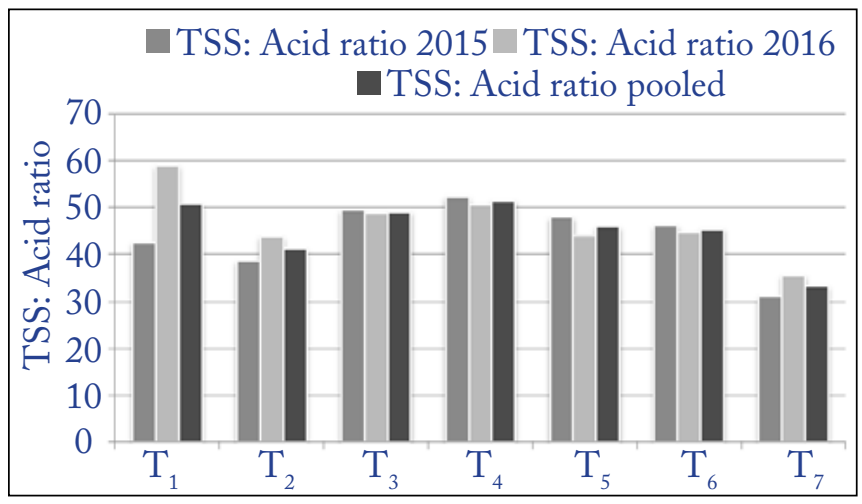

Figure 2: Effect of different sources of potassium on TSS: Acid ratio of litchi cv. Bombai

Considerable improvement in fruit quality with potassium application has been observed which increased TSS, total sugar, reducing sugar, ascorbic acid and anthocyanin content of fruit. Among the different treatments under study application of $\mathrm{K}_{2} \mathrm{SO}_{4} @ 2 \%$ proved most effective in improving the quality of fruits. Higher fruit quality especially higher sugar content can be explained by the role of potassium in carbohydrate synthesis, breakdown and translocation along with the synthesis of protein and neutralization of physiologically important organic acids (Tisdale and Nelson, 1966). Potassium is responsible for energy production in the form of ATP and NADH in chloroplast by maintaining a balance in electric charges in the plant system. Beside this, potassium is also involved in phloem loading and unloading of sucrose and amino acids and storage in the form of starch in developing fruits by activating the enzyme starch synthase (Mengel and Kirkby, 1987). Plants require potassium for the production of high-energy molecules (Wallingford, 1973). This energy is required for all synthetic processes involved in plant metabolism, resulting in the production of carbohydrates, protein and lipids, which express the quality of the crops. Potassium supply can increases the sugar: acid ratio because of an increase in sugars as well as a decrease in acidity (Vadivelu and Shanmugavelu, 1978). Potassium application also favors the conversion of starch into simple sugar during ripening by activating the sucrose system enzyme. Neutralization of organic acids due to high potassium levels in tissues could have also resulted in a reduction of acidity (Tisdale and Nelson, 1966). Beneficial effects of $\mathrm{K}_{2} \mathrm{SO}_{4}$ and other sources were also observed by Dutta et al. (2011) in mango. Das et al. (2017) opined that the beneficial effect of $\mathrm{K}_{2} \mathrm{SO}_{4}$ may be due to the fact that $\mathrm{K}_{2} \mathrm{SO}_{4}$ contains considerably more $\mathrm{SO}_{4}^{-2}$ than other sources. An increased amount of anthocyanin in litchi fruit due to potassium application may be due to activation of enzymes that are responsible for anthocyanin synthesis. Similar results were also obtained by Yao et al. (2014) in litchi cv. 'Feizixiao'

\subsection{Effect of different sources of potassium on leaf mineral content of litchi plant co. Bombai}

Data on the effect of different sources of potassium on different leaf mineral content of litchi plant cv. Bombai has been presented in Table 4.

The leaf nutrient content of the litchi plant both macro and micronutrients showed statistically significant variation with the application of different sources of potassium. A perusal of pooled data in Table 4 revealed that application of $\mathrm{K}_{2} \mathrm{SO}_{4} @ 2 \%\left(\mathrm{~T}_{4}\right)$ showed a maximum of $1.90 \%$ leaf $\mathrm{N}$ content followed by $1.86 \%$ in $\mathrm{T}_{6}(\mathrm{KCl} 2 \%)$ while the minimum leaf nitrogen content of $1.59 \%$ was found in $\mathrm{T}_{7}$ (control) plants. The application of different $\mathrm{K}$ salts significantly increased the phosphorus content of the leaf. Maximum leaf phosphorus content $0.28 \%$ was obtained with application of $\mathrm{T}_{4}$ followed by $0.24 \%$ in $\mathrm{T}_{3}\left(\mathrm{~K}_{2} \mathrm{SO}_{4} 1 \%\right)$ and $\mathrm{T}_{2}\left(\mathrm{KNO}_{3} 2 \%\right)$ while control plant recorded minimum $(0.19 \%)$ content. Leaf $\mathrm{K}$ nutrient content varied between 0.89 and $0.78 \%$ with the highest $0.89 \%$ was recorded from $\mathrm{T}_{4}$ at par with $0.87 \%$ in $\mathrm{T}_{2}\left(\mathrm{KNO}_{3} 2 \%\right)$ while the minimum leaf potassium content of $0.78 \%$ was found in $\mathrm{T}_{7}$ (control) plants. Pooled data also revealed that maximum leaf calcium content of $0.77 \%$ was obtained from $\mathrm{T}_{4}\left(\mathrm{~K}_{2} \mathrm{SO}_{4} 2 \%\right)$ followed by $0.67 \%$ in $\mathrm{T}_{6}(\mathrm{KCl} 2 \%)$ which was at par with $\mathrm{T}_{4}$ while the minimum leaf calcium content of $0.58 \%$ was found from control plants. The leaf micronutrient content was also significantly influenced by the application of different sources of potassium. Among them here also application of $\mathrm{K}_{2} \mathrm{SO}_{4} @ 2 \%\left(\mathrm{~T}_{4}\right)$ pooled data recorded maximum leaf zinc 
Table 4: Effect of different sources of potassium on leaf mineral content of litchi plant cv. Bombai

\begin{tabular}{lcccccc}
\hline Treatments & $\begin{array}{c}\text { Nitrogen } \\
(\%)\end{array}$ & $\begin{array}{c}\text { Phosphorus } \\
(\%)\end{array}$ & Potassium (\%) & Calcium (\%) & Zn (ppm) & B (ppm) \\
\hline $\mathrm{T}_{1}$ & $1.77^{\mathrm{ab}}$ & $0.22^{\mathrm{ab}}$ & $0.83^{\mathrm{ab}}$ & $0.60^{\mathrm{a}}$ & $49.45^{\mathrm{ab}}$ & $16.57^{\mathrm{bc}}$ \\
$\mathrm{T}_{2}$ & $1.82^{\mathrm{ab}}$ & $0.24^{\mathrm{bc}}$ & $0.87^{\mathrm{b}}$ & $0.60^{\mathrm{bc}}$ & $61.98^{\mathrm{bc}}$ & $17.30^{\mathrm{bc}}$ \\
$\mathrm{T}_{3}$ & $1.85^{\mathrm{ab}}$ & $0.24^{\mathrm{bc}}$ & $0.85^{\mathrm{b}}$ & $0.63^{\mathrm{bc}}$ & $52.00^{\mathrm{abc}}$ & $16.31^{\mathrm{b}}$ \\
$\mathrm{T}_{4}$ & $1.90^{\mathrm{b}}$ & $0.28^{\mathrm{c}}$ & $0.89^{\mathrm{b}}$ & $0.77^{\mathrm{d}}$ & $67.17^{\mathrm{c}}$ & $19.57^{\mathrm{d}}$ \\
$\mathrm{T}_{5}$ & $1.76^{\mathrm{b}}$ & $0.23^{\mathrm{b}}$ & $0.84^{\mathrm{b}}$ & $0.63^{\mathrm{bc}}$ & $51.17^{\mathrm{abc}}$ & $17.39^{\mathrm{bc}}$ \\
$\mathrm{T}_{6}$ & $1.86^{\mathrm{b}}$ & $0.23^{\mathrm{b}}$ & $0.86^{\mathrm{b}}$ & $0.67^{\mathrm{c}}$ & $61.83^{\mathrm{bc}}$ & $18.21^{\mathrm{cd}}$ \\
$\mathrm{T}_{7}$ & $1.59^{\mathrm{a}}$ & $0.19^{\mathrm{a}}$ & $0.78^{\mathrm{a}}$ & $0.58^{\mathrm{ab}}$ & $43.68^{\mathrm{a}}$ & $13.10^{\mathrm{a}}$ \\
$\mathrm{SEm} \pm$ & 0.06 & 0.01 & 0.02 & 0.03 & 4.33 & 0.59 \\
$\mathrm{DMRT} p=0.05$ & $\mathrm{~S}$ & $\mathrm{~S}$ & $\mathrm{~S}$ & $\mathrm{~S}$ & $\mathrm{~S}$ & $\mathrm{~S}$ \\
\hline
\end{tabular}

$\mathrm{T}_{1}: \mathrm{KNO}_{3} 1 \% ; \mathrm{T}_{2}: \mathrm{KNO}_{3} 2 \% ; \mathrm{T}_{3}: \mathrm{K}_{2} \mathrm{SO}_{4} 1 \% ; \mathrm{T}_{4}: \mathrm{K}_{2} \mathrm{SO}_{4} 2 \% ; \mathrm{T}_{5}: \mathrm{KCl} 1 \% ; \mathrm{T}_{6}: \mathrm{KCl} 2 \% ; \mathrm{T}_{7}:$ Control

content $(67.17 \mathrm{ppm})$ followed by $(61.98 \mathrm{ppm})$ in $\mathrm{T}_{2}\left(\mathrm{KNO}_{3}\right.$ $2 \%)$ and maximum leaf boron content (19.57 ppm) followed by $18.21 \mathrm{ppm}$ from $\mathrm{T}_{6}(\mathrm{KCl} 2 \%)$ while the minimum zinc content $43.68 \mathrm{ppm}$ and boron content $(13.10 \mathrm{ppm})$ was obtained from $\mathrm{T}_{7}$ (control) plants.

The effect of improved soil nutrient availability coupled with better physical conditions of soil was reflected in increased uptake of macronutrients under different sources of potassium significantly improving the Nitrogen, Phosphorus, Potassium, Calcium, Zincand Boron content of the leaf. Application of Potassium sulphate $\left(\mathrm{K}_{2} \mathrm{SO}_{4}\right)$ at $2 \%$ recorded the maximum Nitrogen, Phosphorus and Potassium and other micro-nutrient content $(\mathrm{Zn}, \mathrm{B})$ of the leaf while minimum value was recorded from control plants. Dutta and Dhua (2005) recorded similar observation in Mango cv. Himsagar. They opined that different sources of potassium significantly increased the Nitrogen, Phosphorus and Potassium and other micronutrient content of mango leaf. Studies have also indicated that $\mathrm{K}$ can enhance litchi leaf photosynthesis and nutrient accumulation, which are necessary for the following year's production (Yang et al., 2015b). It has been also reported that the addition of $\mathrm{K}$ fertilizer as foliar spray may extend the functional period of leaves, thus improving the photosynthetic rate and stimulating the crops (Zheng et al., 2002). Thus this observation collaborates with the present study.

\section{CONCLUSION}

A mong the different sources of potassium application of $\mathrm{K}_{2} \mathrm{SO}_{4} @ 2 \%$ showed the highest plant girth, fruit retention $\mathrm{m}^{-2}$, yield and other yield attributes. TSS, total sugar, and lowest reducing sugar with highest ascorbic acid, anthocyanin content and maximum mineral content of leaf. Finally, it can be concluded that $\mathrm{K}_{2} \mathrm{SO}_{4} @ 2 \%$ was most effective in improving the plant character, yield, physico-chemical properties and leaf nutrient content in Indo-Gangetic plain of West Bengal.

\section{REFERENCES}

Anonymous., 2018. Fruits. Indian Horticulture Database 2017-18 (Second Advance Estimate), National Horticulture Board, Ministry of Agriculture, Govt. of India. Available at: http://nhb.gov.in. $14^{\text {th }}$ September, 2017.

Anonymous, 2000. Association of Official Agricultural Chemists, Official Methods of Analysis, $15^{\text {th }}$ ed. A.O.A.C., Washington, DC.

Casanas, R.R., Gonzalez, M., Rodriguez, E., Marrero, A., Diaz, C., 2002. Chemometric studies of chemical compounds in five cultivars of potatoes from tenerife. Journal of Agricultural and Food Chemistry, 50, 2076-2082.

Cline, R.A., Bradt, O.A., 1980. The effect of source and rate of potassium on the performance of 'concord' grape vine grown on clay loam soil. American Society of Horticultural Science. 105(5), 650-653.

Cohen, A.,1976. Citrus fertilization. IPI Bull No. 4. International Potash Institute, Bern, Switzerland.

Das, K., Roy, M., Roy, D., Dutta, P., 2017. Influence of different sources of potassium on fruit quality and shelf-life of mango cv. Himsagar. Environment \& Ecology 35(2C), 1318-1322.

Dutta, P., Ahmed, B., Kundu, S., 2011. Effect of different sources of potassium on yield, quality and leaf mineral content of mango in West Bengal. Better crops South Asia 5(1), 16-18.

Dutta, P., Dhua, R.S., 2005. Foliar spray of potassium for high yield and quality of Himsagar mango. The Horticulture Journal 18(3), 153-156.

Ghosh, S.P., 2001. World trade in litchi: past, present and 
future. Acta Horticulturae, 558, 23-30.

Gill, P.P.S., Ganaie, M.Y., Dhillon, W.S., Singh, N.P., 2012. Effect of foliar sprays of potassium on fruit size and quality of 'Patharnakh' pear. Indian Journal of Horticulture 69(4), 512-516.

Gross, J., 1991. Carotenoides. In: gross, J. (Ed), Pigments in vegetables: Chlorophylls and carotenoides. Van Nostrand Reinhold, New York, 275-278.

Hopkins, F., 1963. Vitammin-C. In: Braverman, J.B.S. (Ed), The biochemistry of foods. Elsevier, New York., 205-210.

Jackson, M.L., 1967. Soil chemical analysis. Parentice Hall of India Pvt. Ltd., New Delhi.

Lindsay, W.L., Norvell, W.A., 1978. Development of DTPA soft test for zinc, iron, manganese and cupper. Soil Science Society of America Journal 42(3), 421428. doi:10.2136/sssaj1978.03615995004200030009x

Mandal, D., Sarkar, A., Ghosh, B., 2017. Effect of chemicals and cincturing on quality of litchi fruit cv. bombai. International Journal of Economic Plants 4(1), 010-012.

Mengel, K., Kirkby, E.A., 1987. Principles of plant nutrition. IPI, International Potash Institute, Bern, Switzerland, 436-437.

Menzel, C.M., 1983. The control of floral initiation in lychee: A review. Scientia Horticulturae 21, 201-215.

Menzel, C.M., Simpson, D.R., 1987. Lychee nutrition: A review, Scientia Horticulturae 31, 195-234.

Murray, D.B., 1960. The effect of deficiencies of the major nutrients on growth and leaf analysis of banana. Tropical Agriculture TRIN, 37, 97-106.

Nijjar, G.S., 1990. Nutrition of fruit trees, Kalyani Publishers, $2^{\text {nd }} E d$, New Delhi, Ludhiana

Pathak, P.K., Mitra, S.K., 2010. Rate and time of potassium fertilization influence yield and quality of litchi. Proc. 3rd IS on Longan, Lychee \& Other Fruit. Acta Horticulturae, 863, 235-242.

Priyadarshi, V., Hota, D., Karna, A.K., 2018. Effect of growth regulators and micronutrients spray on chemical parameters of litchi (Litchi chinensis Sonn.) cv. Calcuttia. International Journal of Economic Plants 5(3), 99-103.

Ranganna, S., 2003. Handbook of analysis and quality control for fruit and vegetable products. Tata McGraw Hill Publishing Company Limited 7, West Patel Nagar, New Delhi.

Sau, S., Ghosh, B., Sarkar, S., 2016. Correlation and path analysis studies for growth and yield contributing traits in guava (Psidium guajava L.) as affected by micronutrient application. Annals of Plant and Soil Research 18, 370-374.

Singh, V.P., Kumar, G., Singh, A.K., 2007. Effect of water soluble fertilizer 'Polyfeed' on physicochemical attributes of litchi fruits cv. Rose Scented. Progressive Agriculture 7, 22-24.

Stern, R.A., Stern, D., Harpaz, M., Gazit, S., 2000. Applications of 2,4,5-TP, 3,5,6-TPA and combinations thereof increases lychee fruit size and yield. HortScience 35, 661-664.

Tisdale, S.F., Nelson, W.L., 1966. Soil fertility and fertilizer. Macmillan Co. London, 81.

Vadivelu, E., Shanmugavelu, K.G., 1978. Effect of increasing rates of potash on the quality of banana cv. Robusta. Potash Review 24, 1-4.

Wallingford, W., 1973. Function of potassium in plants. In: Potassium for agriculture. Potash and Phosphate Inst., Atlanta. GA, 10-27.

Yang, B., Li, G., Yang, S., Zhaohuan, H., Zhou, C., 2015a. Effect of application ratio of potassium over nitrogen on litchi fruit yield, quality, and storability. Hort Science 50(6), 916-920.

Yang, B., Wang, J., Zhao, M., Liu, Y., Wang, W., Jiang, Y., 2006. Identification of polysaccharides from pericarp tissues of litchi (Litchi chinensis Sonn.) fruit in relation to their antioxidant activities. Carbohydrate Research, 341(5), 634-638.

Yang, B.M., Yao, L.X., Li, G.L., He, Z.H., Zhou, C.M., 2015b. Dynamic changes of nutrition in litchi foliar and effects of potassium-nitrogen fertilization ratio. Journal of Soil Science and Plant Nutrition 15(1), 98-110.

Yao, L.X., Li, G.L., Yang, B.M., He, Z.H., Zhou, C.M., 2014. Effect of application ratio of potassium over nitrogen on litchi growth and fruit quality. Proc. Cronje, R. (Ed.), Fourth IS on Lychee, Longan and Other Sapindaceae Fruits. Acta Horticulturae 1029, 199-208.

Zheng, B.S., Cheng, X.J., Jiang, D.A., Weng, X.Y., 2002. Effects of potassium on Rubisco, RCA and photosynthetic rate of plant. Journal of Zhejiang A\&F University 19(1), 104-108. 